\title{
GAMBARAN TINGKAT KECEMASAN KORBAN GEMPA LOMBOK
}

\author{
Zurriyatun Thoyibah, Dewi Nur Sukma Purqoti", Elisa Oktaviana \\ Staf Pengajar Program Studi Ilmu Keperawatan STIKES YARSI Mataram \\ E-mail: purqotidewi87@gmail.com
}

\begin{abstract}
ABSTRAK
Gempa bumi secara konsisten terbukti berhubungan dengan masalah kesehatan mental seperti cemas, depresi dan gangguan stres pasca-trauma segera setelah bencana. Kondisi tersebut akan semakin memburuk bila tidak dideteksi sejak dini dan ditangani dengan baik, sehingga membutuhkan pelayanan kesehatan mental (trauma healing). Kecemasan yang berlebihan dapat mempunyai dampak yang merugikan pada pikiran serta tubuh bahkan dapat menimbulkan penyakit fisik. Tujuan: Penelitian ini bertujuan untuk mengetahui tingkat kecemasan korban Gempa Lombok. Metode: Penelitian ini merupakan penelitian yang bersifat deskriptif dengan pendekatan cross sectional. Tehnik pengambilan sampel yang digunakan yakni dengan Purposive Sampling dengan jumlah sampel 40 orang. Instrumen yang digunakan dalam penelitian ini adalah kuesioner Hamilton Anxiety Rating Scale (HARS). Analisis data yang digunakan adalah univariat dengan data disajikan dalam bentuk narasi, tabel distribusi frekuensi dan persentase. Hasil: Hasil penelitian menunjukkan bahwa 15 responden mengalami kecemasan ringan (37,5\%) dan 25 responden mengalami kecemasan sedang (62,5\%). Diskusi: Selain dampak fisik, kejadian gempa juga menimbulkan masalah kesehatan jiwa, salah satunya rasa cemas yang masih dirasakan responden meskipun 8 bulan setelah gempa. Sebagian responden mengelaman kecemasan dalam berbagai kategori sedang dengan skor berbeda. Hal tersebut terjadi dipengaruhi oleh jenis kelamin, usia, tingkat pendidikan dan pengalaman saat terjadi gempa. Kesimpulan: Sebagian besar responden pada penelitian ini masih mengalami kecemasan sedang.
\end{abstract}

Kata Kunci: Gempa bumi, kecemasan

\section{The Level of Anxiety of Lombok Earthquake Survivors}

\section{ABSTRACT}

Earthquakes are consistently proven to be related to mental health issues such as anxiety, depression and post-traumatic stress disorders immediately after disaster. This condition will deteriorate if not detected early and well handled, so it requires mental health services (trauma healing). Excessive anxiety can have a detrimental impact on the mind as well as the body can even cause physical illness. Objectives: The study aims to determine the level of anxiety of Lombok earthquake survivors. Methods: This research is a descriptive study with a cross sectional approach. Sampling techniques used by purposive Sampling with a sample number of 40 people. The instruments used in this study are the Hamilton Anxiety Rating Scale (HARS) questionnaire. Data analysis used is univariate with data presented in narrative form, frequency distribution table and percentage. Results: The results showed that 15 respondents experienced mild anxiety (37.5\%) and 25 respondents experienced moderate anxiety (62.5\%). Discussion: In addition to physical impact, earthquake incidence also raises mental health problem, one of which is anxiety that was felt by respondents even 8 months after the earthquake. Respondents partly experienced anxiety in the medium category with different score. This can be influenced by gender, age, level of education and experience in the event of an earthquake. Conclusion: most of the respondents in this study is still experiencing moderate anxiety.

Keywords: Earthquakes; anxiety 


\section{LATAR BELAKANG}

Bencana gempa yang terjadi di Lombok sejak tanggal 29 Juli 2018 membawa dampak yang luar biasa terhadap semua aspek kehidupan baik aspek fisik, psikologis, dan sosial. Korban gempa tidak hanya mengalami masalah darurat seperti pembangunan, makanan, kondisi fisik akibat gempa namun juga masalah kesehatan mental. Setelah peristiwa bencana, sebagian besar populasi korban bencana tetap memiliki reaksi psikologis yang normal, sekitar $15-20 \%$ akan mengalami gangguan mental ringan atau sedang yang merujuk pada kondisi Post Traumatic Stress Disorder (PTSD), sementara 3-4\% akan mengalami gangguan berat seperti psikosis, depresi berat dan kecemasan yang tinggi (WHO, 2013). Hasil penelitian yang dilakukan oleh Dwidiyanti, dkk (2018) pada korban gempa Lombok menunjukkan bahwa sebanyak sebanyak $85,2 \%$ mengalami gejala neurosis, $29,5 \%$ mengalami gejala psikotik, dan $64,7 \%$ korban mengalami gejala PTSD. Sedangkan pada anak korban gempa ditemukan $85,11 \%$ mengalami kecemasan normal dan $14,89 \%$ mengalami kecemasan berat (Thoyibah, dkk, 2019).

Gempa bumi secara konsisten terbukti berhubungan dengan masalah kesehatan mental seperti depresi dan gangguan stres pasca-trauma segera setelah bencana. Kondisi tersebut akan semakin memburuk bila tidak dideteksi sejak dini dan ditangani dengan baik, sehingga membutuhkan pelayanan kesehatan mental (trauma healing).

Kecemasan yang berlebihan dapat mempunyai dampak yang merugikan pada pikiran serta tubuh bahkan dapat menimbulkan penyakit-penyakit fisik. Kecemasan juga dianggap sebagai salah satu faktor penghambat dalam proses belajar yang dapat mengganggu kinerja fungsi-fungsi kognitif sehingga kesulitan dalam pemecahan masalah dan dapat menurunkan produktivitas seseorang. Pendekatan konseling dengan muatan nilainilai spiritual diharapkan membuat korban gempa lebih tahan serta bersemangat dalam berusaha untuk mencapai kehidupan yang membahagiakan dan dapat ikhlas menerima cobaan dan mengambil hikmah di balik peristiwa gempa.

Terjadinya gempa yang berkali-kali menimbulkan kecemasan di kalangan warga NTB, khususnya yang merasakan dampak langsung dari gempa Lombok atau dalam hal ini disebut survivor gempa Lombok. Jika hal ini dibiarkan begitu saja dikhawatirkan kondisi kecemasan ini akan membawa dampak negatif bagi kehidupan korban gempa bahkan tidak hanya dari segi psikologis saja tapi fisik pun akan tergangggu.

\section{METODE}

Penelitian ini merupakan penelitian kuantitatif. Desain penelitian yang bersifat deskriptif dengan pendekatan cross sectional yaitu suatu jenis penelitian yang pengukuran variabel-variabelnya dilakukan hanya satu kali pada suatu saat. Pengambilan sampel menggunakan teknik purposive sampling dan didapatkan 40 responden.

Proses pelaksanaan penelitian dimulai pada bulan Maret 2019 dengan agenda seleksi sampel yang akan menjadi responden yang dilihat berdasarkan adanya kecemasan yang dialami. Selanjutnya dilakukan proses skrining responden sesuai dengan kriteria inklusi. Kriteria inklusi pada penelitian ini adalah bersedia menjadi responden, berdomisili di Desa Grimak Indah dan Desa Gunung Sari, bisa baca tulis serta tidak mengalami gangguan pendengaran. Kriteria eksklusi dalam penelitian ini adalah tidak kooperatif dalam proses penelitian, mengalami cacat fisik yang menyebabkan tidak dapat menjawab kuesioner. Pada penelitian ini peneliti mendapatkan 40 responden yang mengalami kecemasan 
ringan dan sedang yang berasal dari 2 desa yang menjadi lokasi penelitian yaitu di Desa Gerimak Indah dan Desa Gunung Sari, Kabupaten Lombok Barat.

Instrumen yang digunakan adalah kuesioner Hamilton Anxiety Rating Scale (HARS). HARS merupakan pengukuran kecemasan yang didasarkan pada munculnya gejala-gejala pada individu yang mengalami kecemasan. Instrumen ini telah diuji validitas dan reliabilitasnya oleh Fu'ad, Dayal, \& Fuad (2015). Hasil uji validitas tiap item pertanyaan $>0,05$ dan nilai reliabilitasnya $0,793>0,6$, sehingga kuesioner ini dapat dinyatakan valid dan reliabel. Interpretasi dari kuesioner ini dikatakan tidak ada kecemasan jika skor $<6$, kecemasan ringan skor 6-14, kecemasan sedang skor 15-27, kecemasan berat skor 28-36, dan kecemasan berat sekali/panik jika skor $>36$.

Penelitian ini sudah melalui tahap uji etik dan dinyatakan layak untuk mendapatkan izin etik dari komite etik RSUD Provinsi NTB dengan nomor 070.1/14/KEP/2019. Pengolahan data karakteristik responden ini menggunakan statistic descriptive dan disajikan sesuai dengan jenis data.

\section{HASIL}

Karakteristik responden pada penelitian ini meliputi umur, jenis kelamin, dan pendidikan (Tabel 1).

Tabel 1. Distribusi frekuensi data karakteristik responden

\begin{tabular}{llll}
\hline Variabel & Min & Max & \multicolumn{2}{c}{ Median } \\
\hline Umur (tahun) & 25 & 79 & \multicolumn{2}{c}{45} \\
\hline \multirow{2}{*}{ Karakteristik } & Kategori & Frekuensi & Persentase (\%) \\
& & & \\
\hline \multirow{2}{*}{ Jenis Kelamin } & Laki-laki & 2 & 5 \\
& Perempuan & 38 & 95 \\
\hline & Total & 40 & 100,0 \\
\hline & Tidak Sekolah & 14 & 35 \\
Pendidikan & Tidak Tamat SD & 6 & 15 \\
& SD & 10 & 25 \\
& SMP & 6 & 15 \\
& SMA & 4 & 10 \\
\hline & Total & 40 & 100,0 \\
\hline
\end{tabular}


Tabel 2. Distribusi frekuensi tingkat kecemasan

\begin{tabular}{llll}
\hline No & Tingkat Kecemasan & Jumlah & Persentase (\%) \\
\hline 1 & Ringan & 15 & 37,5 \\
\hline 2 & Sedang & 25 & 62,5 \\
\hline 3 & Berat & 0 & 0,0 \\
\hline 4 & Panik & 0 & 0,0 \\
\hline Total & & 40 & $\mathbf{1 0 0 , 0}$ \\
\hline
\end{tabular}

Berdasarkan tabel 1, didapatkan bahwa usia paling muda adalah 25 tahun dan usia paling tua adalah 79 tahun. Jumlah responden berjenis kelamin laki-laki sebanyak 2 orang $(5,0 \%)$ dan perempuan sebanyak 38 orang $(95,0 \%)$, sehingga dalam penelitian ini mayoritas jenis kelaminnya adalah perempuan. Berdasarkan tingkat pendidikan dapat diketahui bahwa mayoritas responden dalam penelitian adalah yang tidak sekolah. Berdasarkan tabel 2, dapat diketahui bahwa kecemasan yang dirasakan responden lebih dari setengahnya mengalami kecemasan dalam kategori sedang.

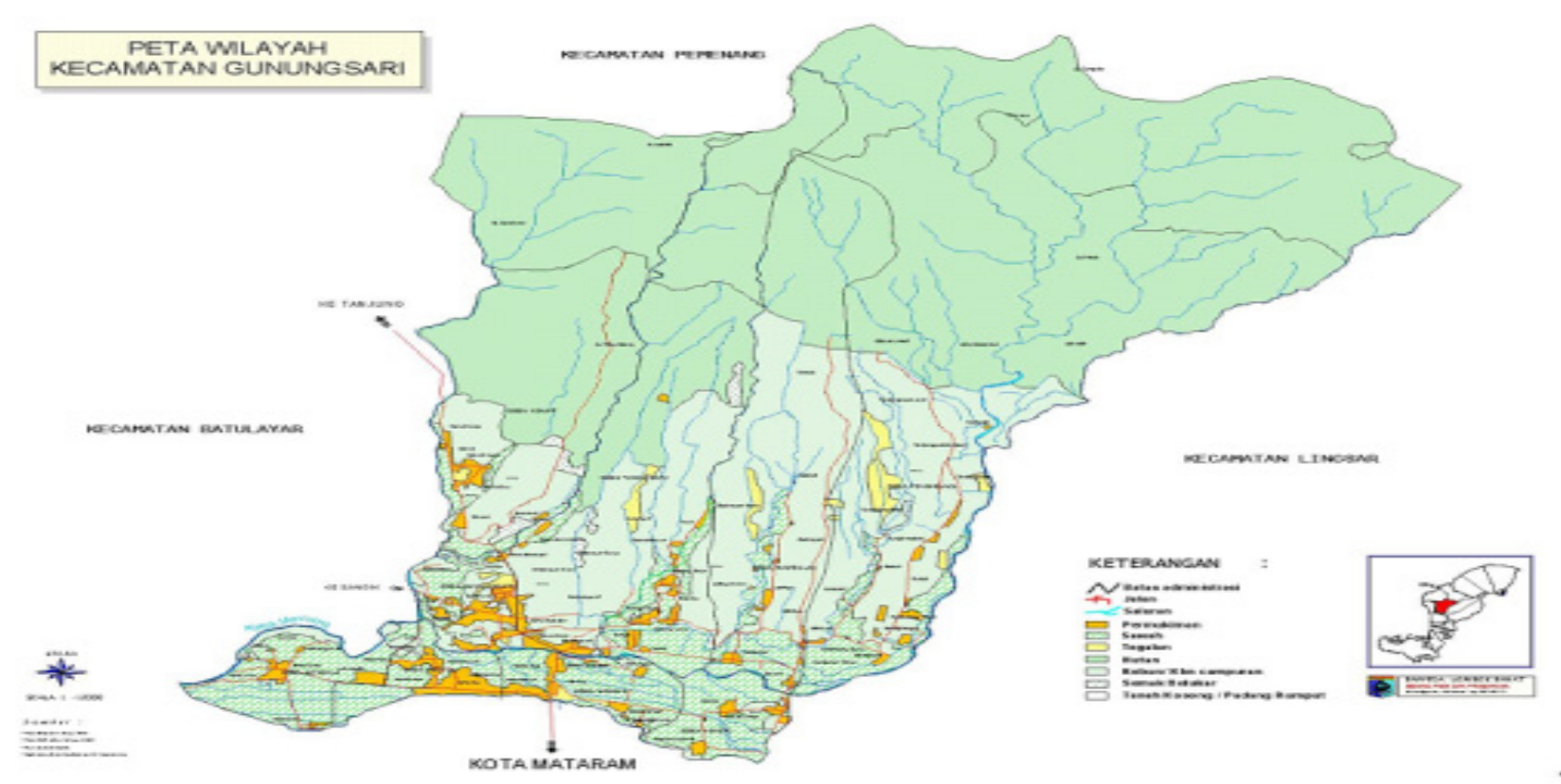

Gambar 1. Peta lokasi penelitian (Desa Gunung Sari) 


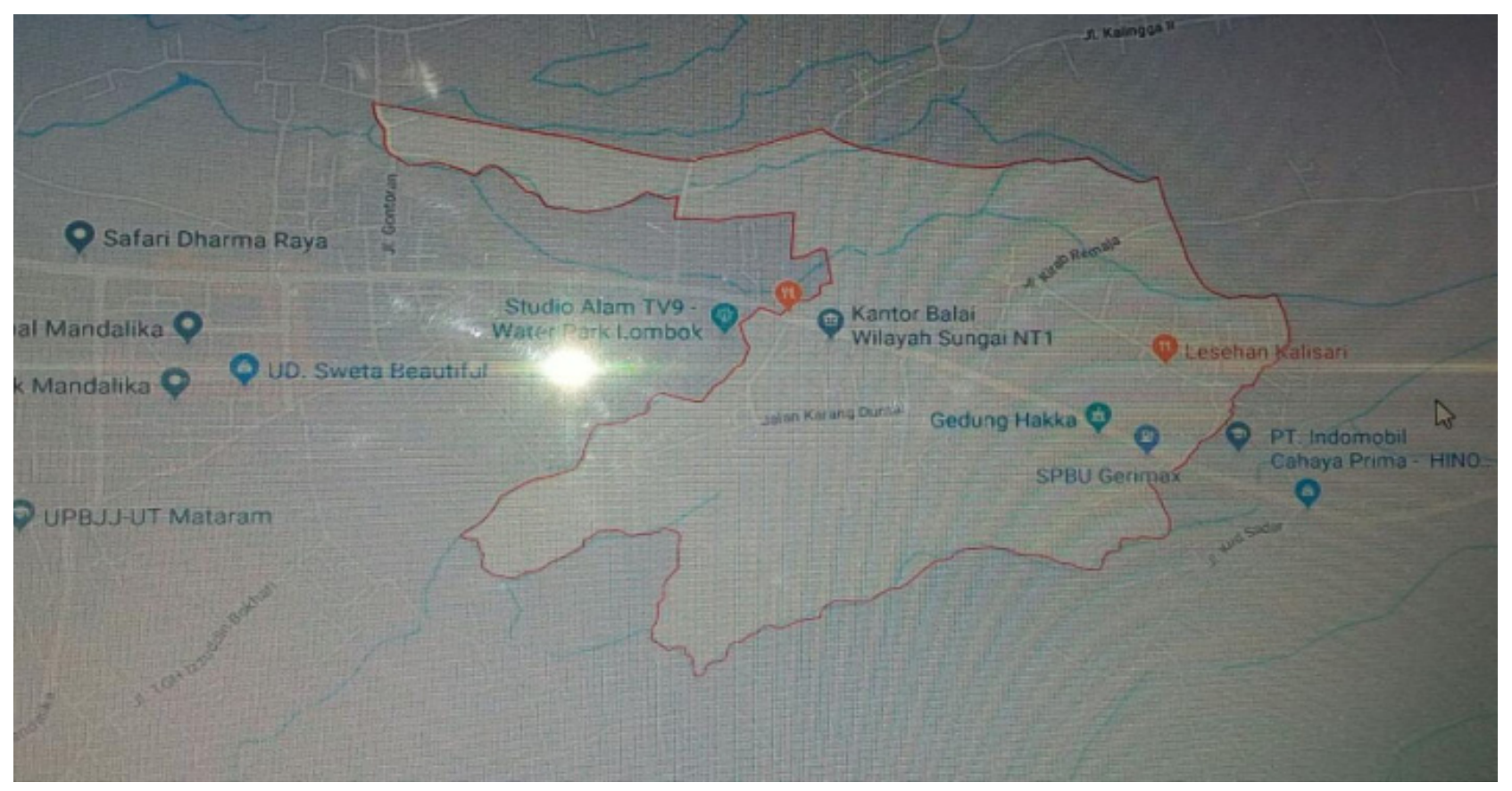

Gambar 2. Peta lokasi penelitian (Desa Gerimak Indah)

Desa Gunung Sari (Gambar 1) dan Desa Gerimak Indah (Gambar 2) merupakan desa yang mengalami dampak kerusakan gempa cukup parah, dimana rumah warga rusak berat, terdapat korban meninggal dan saat dilakukan skrining warga masih mengalami perasaan cemas dalam kategori ringan dan sedang. Mayoritas masyarakat di desa ini adalah suku Sasak yang masih sangat meyakini adanya pertolongan dari Tuhan ketika adanya suatu bencana.

\section{DISKUSI}

Kejadian gempa di Lombok pada tahun 2018, pertama kali terjadi pada tanggal 29 Juli 2018 dengan kekuatan 6,4 Magnitudo momen (Mw) yang mengakibatkan kerusakan dan menimbulkan korban jiwa, terutama di Kabupaten Lombok Timur dan Lombok Utara. Gempa berikutnya terjadi tanggal 5 Agustus 2018 dengan kekuatan $7 \mathrm{Mw}$ yang menimbulkan kerusakan parah dan banyak korban jiwa di hampir seluruh wilayah Lombok, khususnya Lombok Barat dan Lombok Utara. Selanjutnya gempa susulan juga terjadi pada tanggal 9 Agustus 2018 dengan kekuatan 6,2 Mw. Kabupaten Lombok Barat merupakan salah satu kabupaten terdampak gempa yang cukup parah, salah satunya di Desa Gunung Sari dan Desa Gerimak Indah. Ratusan rumah warga hancur (rusak berat) dan banyak warga yang mengalami luka, baik luka ringan maupun luka berat seperti fraktur femur (patah tulang kaki).

Selain dampak fisik, kejadian gempa juga menimbulkan masalah kesehatan. jiwa, salah satunya rasa cemas. Kecemasan adalah respon terhadap situasi tertentu yang mengancam dan merupakan hal yang normal terjadi. Kecemasan merupakan pengalaman individu yang bersifat subyektif berupa perasaan takut, khawatir, kesulitan dan kesusahan terhadap sesuatu yang realistis 
maupun tidak realistis dan dirasakan individu sebagai sesuatu yang tidak menyenangkan.

Hasil analisis univariat menunjukkan bahwa sebagian besar responden mengalami kecemasan dalam kategori sedang dengan skor yang berbeda. Instrumen yang digunakan dalam penelitian ini adalah kuesioner Hamilton Anxiety Rating Scale (HARS), yang membagi kecemasan menjadi 5 tingkat kecemasan, yaitu tidak cemas, cemas ringan, cemas sedang, cemas berat dan panik. Gejala kecemasan yang dirasakan responden berdasarkan kuesioner HARS antara lain takut, memiliki firasat buruk, merasa tegang dan gelisah, takut gelap, takut saat sendiri, takut kerumunan orang banyak dan mudah terkejut, susah tidur, tidur tidak nyenyak, menurunnya konsentrasi dan minat, serta gejala somatik seperti sakit kepala, nyeri otot, otot tegang, sulit menelan, gemetar, sering BAK, jantung berdebar dan merasa sesak.

Hasil ini sejalan dengan penelitian yang dilakukan oleh Dwidiyanti, dkk pada tahun 2018 yang menunjukkan bahwa sebanyak $85,2 \%$ korban gempa mengalami gejala neurosis, 29,5\% korban mengalami gejala psikotik, dan $64,7 \%$ korban mengalami gejala PTSD. Hasil studi kualitatif keluhan korban gempa menunjukkan bahwa hampir seluruh korban menyatakan takut, cemas untuk memasuki rumah akibat peristiwa gempa, mengalami masalah keluarga dan ekonomi dan isu makhluk halus serta sakit menjadi masalah aspek spiritual masyarakat korban gempa bumi.

Pada penelitian ini didapatkan responden mengungkapkan bahwa mereka masih merasa takut saat gelap dan saat sendiri. Pada saat mati lampu terutama jika mati lampu pada Minggu malam, responden segera keluar rumah dan bersikap waspada karena merasa trauma dengan gempa besar tahun 2018 yang terjadi pada Minggu malam. Salah satu responden dengan skor kecemasan yang paling tinggi mengungkapkan bahwa responden tersebut masih ditemani ke kamar mandi jika mati lampu. Responden lain menceritakan bahwa mereka sudah mulai menutup pintu rumah dan gerbang tetapi tidak berani dikunci, ada juga yang menyatakan saat ke kamar mandi untuk mandi, BAB atau BAK, belum berani mengunci pintu kamar mandi dari dalam.

Penelitian ini mulai dilaksanakan bulan Maret 2019 atau 8 bulan setelah kejadian gempa. Hasil skrining awal menunjukkan bahwa masyarakat korban gempa masih mengalami kecemasan dalam tingkat ringan dan sedang. Kecemasan yang dialami responden berada dalam kategori sedang, tidak ada responden yang mengalami kecemasan dalam kategori berat dan atau panik.

Tim Crisis and Recovery Center (CRC) Fakultas Psikologi Universitas Gadjah Mada menemukan bahwa 2,5\% dari populasi yang mengalami beban mental pasca gempa bumi akan mengalami kesulitan untuk menyesuaikan diri pada jangka menengah dan panjang. Artinya korban yang selamat akan memerlukan bantuan psikologis mulai dari minggu ke-3 sampai 3 bulan kemudian. Selanjutnya, $1 \%$ dari populasi akan mengalami masalah psikologis pada masa yang lebih lama, yaitu korban yang rumahnya rusak berat atau roboh. Temuan tersebut sejalan dengan hasil penelitian ini, yang tidak menemukan responden dalam kategori cemas berat dan atau panik.

Kecemasan dalam kategori sedang yang masih dialami oleh responden dapat dipengaruhi oleh jenis kelamin, usia, tingkat pendidikan dan pengalaman saat terjadi gempa. Responden pada penelitian ini hampir seluruhnya adalah perempuan. Perempuan lebih cemas akan 
ketidakmampuannya dibanding dengan laki-laki. Laki-laki lebih aktif, eksploratif, sedangkan perempuan lebih sensitif.

Penelitian menunjukkan bahwa lakilaki lebih rileks dibanding perempuan dan perempuan memiliki risiko yang lebih tinggi untuk mengalami ansietas akibat trauma (Feder, dkk, 2013). Penelitian lain juga menemukan bahwa perempuan lebih banyak memikirkan tentang bencana dan memiliki keterikatan emosi yang dalam terhadap keluarga dibanding laki-laki (Dwidiyanti, dkk, 2018). Responden penelitian ini kebanyakan tidak bersekolah atau berpendidikan rendah. Hal ini menjadi faktor risiko stres, gangguan kesehatan jiwa akibat rendahnya pengetahuan mengenai manajeman paska bencana dan trauma healing.

Selain itu, kecemasan yang dialami kemungkinan disebabkan oleh pengalaman buruk saat terjadinya gempa, seperti rumah hancur atau cedera. Bencana menimbulkan berbagai potensi permasalahan kesehatan bagi masyarakat terdampak dan akan dirasakan lebih parah oleh kelompok penduduk rentan termasuk ibu hamil dan orang lanjut usia (Widayatun \& Fatoni, 2013). Hasil penelitian ini menemukan bahwa salah satu responden adalah ibu yang hamil 9 bulan saat terjadinya gempa dan melahirkan di dalam ambulance akibat rusaknya fasilitas kesehatan tingkat pertama (Puskesmas). Responden pada penelitian ini juga sebagian besar adalah lansia, dimana lansia merupakan salah satu kelompok rentan. Hal tersebut menyebabkan responden masih merasakan cemas, meskipun kejadian gempa sudah 8 bulan berlalu.

\section{SIMPULAN}

Dari hasil penelitian ini dapat disimpulkan bahwa responden pada penelitian ini berusia paling muda 25 tahun dan usia paling tua adalah 79 tahun, mayoritas jenis kelaminnya adalah perempuan, dan mayoritas responden dalam penelitian adalah yang tidak sekolah. Berdasarkan tingkat kecemasan yang dirasakan responden, mayoritas responden dalam penelitian ini mengalami kecemasan dalam kategori sedang. Upaya yang dapat dilakukan untuk menurunkan tingkat kecemasan yang dialami melalui memanfaatkan sumbersumber yang ada dalam diri melalui pendekatan spiritual salah satunya dengan teknik konseling spiritual.

\section{DAFTAR PUSTAKA}

Dwidiyanti, M., Hadi, I., Wiguna, R., Ningsih, H. (2018). Gambaran Risiko Gangguan Jiwa pada Korban Bencana Alam Gempa di Lombok Nusa Tenggara Barat. Journal of Holistic Nursing and Health Sience, 1(2): 1-10. Retrieved from https:// ejournal2.undip.ac.id/index.php/ hnhs/article/view/3419

Feder, A., Ahmad, S., Lee, E. J., Morgan, J. E., Sigh, R., Smith, B. W., Southwick, S., M., Charney, D. S. (2013). Coping and PTSD symptoms in Pakistani earthquake survivors: purpose in life, religious coping and social support. J Affect Disord, 147(1-3): 156-163. Doi: 10.1016/j. jad.2012.10.027.

Fu'ad, K., Dayal, G., \& Fuad, A. (2015). Uji validitas dan reliabilitas Hamilton Anxiety Rating Scale terhadap kecemasan dan produktivitas pekerja visual inspection PT. Widatra Bhakti. Retrieved from http://library.itn.ac.id/jurnal/index. php/KADO/article/view.

Thoyibah, Z. Dwidiyanti, M., Mulianingsih, M., Nurmayani, W., \& Wiguna, 
R. (2019). Gambaran dampak kecemasan dan gejala psikologis pada anak korban bencana gempa bumi di Lombok. Holistic Nursing and Health science, 2(1): 31-38.

Widayatun \& Fatoni, A. (2013). Permasalahan kesehatan dalam kondisi bencana: Peran petugas kesehatan dan partisipasi masyarakat. Jurnal Kependudukan Indonesia, 8(1): 37-53.

World Health Organization. (2013). Building back better. Sustainable mental health care after emergencies. Retrieved from http://apps.who. int/iris/beatstream/10665/85377/1/ 978241564571_eng.pdf?ua=1 